\title{
PARASITES OF FRANCISCANA (PONTOPORIA BLAINVILLEI) FROM SÃO PAULO AND PARANÁ STATES, BRAZIL
}

\author{
Juliana Marigo ${ }^{1,2}$, Fernando C.W. Rosas ${ }^{3}$, Ana Luísa V. Andrade ${ }^{4}$ \\ Márcia R. Oliveira ${ }^{5}$, Ricardo A. Dias ${ }^{6}$ and José Luiz Catão-Dias ${ }^{1}$
}

\begin{abstract}
The franciscana, Pontoporia blainvillei, is a threatened small cetacean of the western South Atlantic Ocean and is commonly caught incidentally in fishing nets along its distribution. Detailed studies regarding parasite loads of $P$. blainvillei have been recommended as a tool to evaluated ecological segregation and stock structure. We analyzed metazoan parasites from stomach, intestines and lungs of 41 franciscanas from three close geographical areas: Group 1, Guarujá and Praia Grande

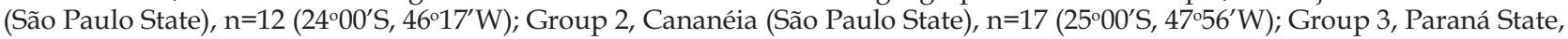
$\mathrm{n}=12\left(25^{\circ} 30^{\prime} \mathrm{S}, 48^{\circ} 23^{\prime} \mathrm{W}\right)$. The sample consists mainly of immature specimens, less than 3 years old. No parasites were found in the lungs analyzed. The acanthocephalan (Polymorphus sp) found in two stomachs were considered occasional. The trematode Hadwenius pontoporiae (Digenea: Campulidae) was the only parasite found in the intestines with prevalence of $100 \%$ for Group $1,82.35 \%$ for Group 2 and 58.33\% for Group 3. The mean intensity of $H$. pontoporiae for Groups 1, 2 and 3 was $39.5,25.05$ and 13.5 parasites per host, respectively. In this study there was a significant difference between the number of parasites among the three groups (Kruskal-Wallis test, $\mathrm{p}=0.012$ ). Groups 2 and 3 are geographically close, and exhibited non-significant differences in the total number of parasites found (Mann-Whitney test, $\mathrm{p}=0.063$ ). Groups 1 and 3, that are further apart geographically, differed significantly in the total number of parasites found (Mann-Whitney test, $p=0.003$ ). Through the analysis of data from the areas where H. pontoporiae was found [i.e. Areas 1, 2, 3 (this study), Rio Grande do Sul State and Argentina], it could be noticed that the prevalence and mean intensity increase as latitude increases. H. pontoporiae may continue to be useful as a biological tag for identifying franciscana's ecological stocks, together with information from genetic, morphometric and other biological studies. However, it is essential that standardized methodology be used in the collection of the parasite data.
\end{abstract}

Resumo - A toninha, Pontoporia blainvillei, é um cetáceo ameaçado do Atlântico Sul Ocidental. Captura acidentais ao longo de sua distribuição são freqüentes. O uso de informações a respeito dos parasitas de $P$. blainvillei é recomendado para avaliar segregações ecológicas e diferenciar estoques populacionais. Estômagos, pulmões e intestinos de 41 animais foram analisados buscando parasitos metazoários. Os animais são provenientes de 3 áreas geográficas próximas: Grupo 1, Guarujá e Praia Grande

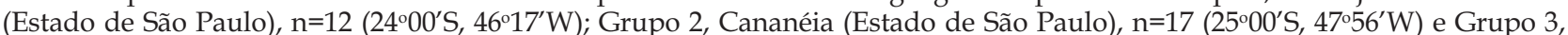

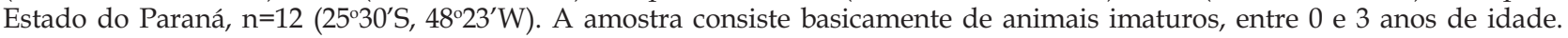
Nenhum parasito foi encontrado nos pulmões analisados. O acantocéfalo Polymorphus sp, encontrado em dois estômagos foi considerado ocasional. O trematóide Hadwenius pontoporiae (Digenea: Campulidae) foi o único parasito encontrado nos intestinos com prevalência de $100 \%$ para o Grupo $1,82,35 \%$ para o Grupo 2 e $58,33 \%$ para o Grupo 3 . A intensidade média de $H$. pontoporiae nos Grupos 1, 2 e 3 foi de 39,5; 25,05 e 13,5 parasitos por hospedeiro, respectivamente. Houve uma diferença significativa entre o número de parasitas dos três grupos (Kruskal-Wallis test, $\mathrm{p}=0,012$ ). Os grupos 2 e 3 são geograficamente mais próximos e não apresentaram diferença significativa (Mann-Whitney test, $\mathrm{p}=0,063$ ), enquanto os grupos 1 e 3 , mais distantes, exibiram uma diferença significativa no número total de parasitas encontrados (Mann-Whitney test, $\mathrm{p}=0,003$ ). Através da análise das áreas onde H. pontoporiae foi encontrado: áreas 1, 2, 3 (este estudo), Estado do Rio Grande do Sul e Argentina, verificou-se uma tendência de aumento da prevalência e intensidade média de acordo com o aumento da latitude. $H$. pontoporiae pode continuar sendo usado como marcador biológico para toninhas, com metodologia padronizada, juntamente com outras características, sempre considerando-se todos os fatores que podem afetar os resultados.

Keywords: Pontoporia blainvillei, parasites, stock identification, western South Atlantic, Brazil.

\section{Introduction}

The franciscana, Pontoporia blainvillei, is considered one of the most threatened small cetacean in the western South Atlantic Ocean (Secchi et al., in press a) and is the most common cetacean incidentally caught in fishing nets along the coast of São Paulo and Paraná states, Brazil (e.g. Rosas, 2000; Bertozzi and Zerbini, 2002; Santos et al., 2002). Studies on the stock structure and abundance of franciscana in its restrict home range are urgently needed to evaluate the impact of this incidental mortality on local populations (Secchi et al., 2001; Secchi et al., in press b).

Parasites have been useful as an additional source of information on various aspects of host biology, including stock identity. Comparisons of infection levels of one or more species of parasites among host groups within a given geographic area can aid in the identification of populations that are segregated, potentially comprising different ecological stocks (e.g. Szidat, 1964; MacKenzie, 1987; Dailey and Vogelbein, 1991; Moser, 1991; Aznar et al., 1995; Balbuena et al., 1995; Aznar et al., 1997a, Walker, 2001). The use of such information as a tool to examine the stock structure of the franciscana has already been recommended (Reeves and Leatherwood, 1994; IBAMA, 1997).

Previous studies of the parasite fauna of franciscana along the coast of southern Brazil (Rio Grande do Sul State), Uruguay and Argentina suggest the occurrence of two segregated populations (Aznar et al., 1995; Andrade, 1996).

\footnotetext{
Departamento de Patologia, Faculdade de Medicina Veterinária e Zootecnia, Universidade de São Paulo. 05508-000, São Paulo, SP, Brazil.

Centro Golfinho Rotador. 53990-000, Fernando de Noronha, PE, Brazil.

${ }^{3}$ Instituto Nacional de Pesquisas da Amazônia. 69011-970, Manaus, AM, Brazil.

${ }^{4}$ Instituto de Biologia, Universidade Federal de Pelotas. 96100-000, Pelotas, RS, Brazil.

${ }^{5}$ Departamento de Zoologia, Universidade Federal do Paraná. Caixa Postal 19020. Curitiba, PR, 81531-970, Brazil.

${ }^{6}$ Departamento de Medicina Veterinária Preventiva e Saúde Animal, Universidade de São Paulo. 05508-000, São Paulo, SP, Brazil.

- Corresponding author: marigo@mtecnetsp.com.br.
} 
However, few parasite data are available for franciscanas from the coastal waters of Santa Catarina up to Espírito Santo states $\left(29^{\circ} 05^{\prime} \mathrm{S}-18^{\circ} 25^{\prime} \mathrm{S}\right)$, and the stock structure of the species along this latitudinal gradient is not completely known.

The aim of this work is to present a preliminary description of the parasite community of specimens of $P$. blainvillei from Paraná and São Paulo states. The results can be useful in stock differentiation for conservation purposes.

\section{Material and Methods}

We analyzed metazoan parasites from the stomach, intestines and lungs of 16 female and 25 male franciscanas. Due to the small sample sizes for some areas, specimens were grouped according to their sampling location (Figure 1). Group $1(n=12)$ includes animals from Guarujá $(n=3)$ and Praia Grande ( $n=9$ ) (ca. $24^{\circ} 00^{\prime} S, 46^{\circ} 17^{\prime} \mathrm{W}$ ), on the central coast of São Paulo State. Group 2 includes

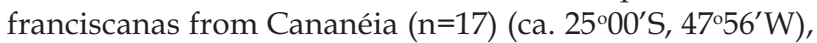
southern São Paulo State. Specimens from Baía de

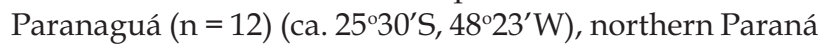
State, were included in Group 3.

Intestines of one franciscana from Ubatuba and one from Itanhaém, São Paulo State, were also sampled.

The total length and gender of each specimen were recorded.
Lungs were opened with scissors inside a plastic tray and all the contents were washed in a sieve (mesh $=150 \mu \mathrm{m})$ to collect parasites. All macroscopic parasites seen during the analysis of food remains in the stomachs were collected. Small and large intestines were identified macroscopically according to Yamasaki et al. (1975). Based on the methodology used by Andrade (1996), the small intestine was divided into five equal-sized sections and only the first third of each section was sampled. The entire large intestine was examined. The intestinal contents were washed in a sieve $($ mesh $=150 \mu \mathrm{m})$ and examined on a stereoscopic microscope (10x) to collect the parasites.

All parasites were fixed and stained according to Dailey (1978) and Gardiner (2000). Species identification was based mainly on Price (1932), Raga et al., (1994), Fernandez et al., (1995) and Yamaguti (1963).

Prevalence equal to or greater than $50 \%$ was used as a criterion to identify the parasite community. Pearson's correlation coefficient was applied to examine the correlation between infection levels (number of parasites per host) and total body length. Kruskal-Wallis and MannWhitney tests were used to compare mean intensity between the groups. A Mann-Whitney test was also applied to compare the mean intensity between males and females. Linear regression was used to examine trends in mean intensity along the latitudinal gradient, based on mean

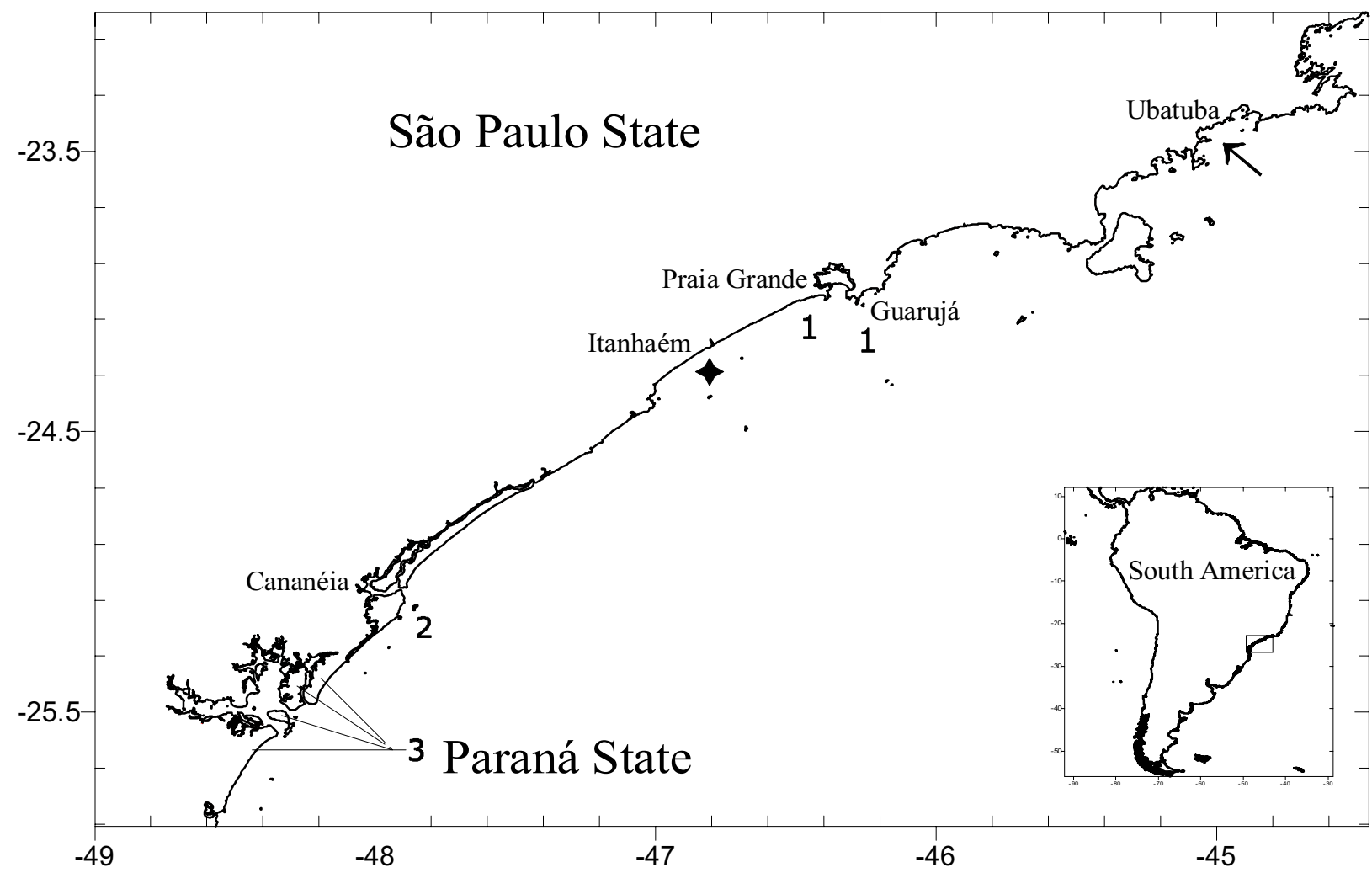

Figure 1. Map of São Paulo and Paraná states, showing the main sampling areas for franciscanas - (Area 1) Group 1: Guarujá and Praia Grande, São Paulo State (n=12); (Area 2) Group 2: Cananéia, São Paulo State (n=17); (Area 3) Group 3: Paraná State $(n=12)$. $(\leftarrow) 1$ animal from Ubatuba, São Paulo State; (F) 1 animal from Itanhaém, São Paulo State. 
intensity and prevalence data from other regions, in addition to the data presented in this study.

Most franciscanas had their age determined by Rosas (2000). A Kruskal-Wallis test was applied to verify if total body length of specimens from the three groups differed. A significance level of 0.05 was used in all tests, unless stated otherwise.

\section{Results and Discussion}

Specimens

Osteological (Pinedo, 1991) and genetic studies (Secchi et al., 1998) suggest the existence of at least two distinct populations of $P$. blainvillei: a smaller northern geographic form (latitudes between $22^{\circ}$ and $27^{\circ} \mathrm{S}$ ) and a larger southern form (latitudes between $32^{\circ}$ and $38^{\circ} \mathrm{S}$ ). Considering the geographic location of the areas sampled, and the lack of a significant difference in the total length between animals from the three groups (Kruskal-Wallis test, $\mathrm{p}=0.388$ ), we believe that all animals examined belong to the northern population.

Rosas (2000) analysed gonads and determined the ages of the same franciscanas examined in this paper. This author estimated that sexual maturity of franciscanas from Groups 2 and 3 is attained when males and females are $112-116 \mathrm{~cm}$ and $122-126 \mathrm{~cm}$ long, respectively (Figure 2), and that the age of attainment of sexual maturity was between 4 and 5 years for both sexes. The age of the animals from these groups ranged from 0 to 16 years, with the majority consisting of immature specimens less than 3 years old. Age data are not available for animals from Group 1; however, based on their mean total length (111.13 \pm $16.40 \mathrm{~cm}$ for females and $107.25 \pm 8.07 \mathrm{~cm}$ for males), it is suspected that most are immature specimens under 4 or 5 years. However, these results should be interpreted with caution because individuals from adjacent geographic locations may show different growth patterns.

\section{Parasite Analysis}

$$
\text { - Lungs }
$$

The lungs of franciscanas from Group 1 have not yet been analyzed. The lungs of the animals from Groups 2 and 3 were not infected by helminths; this is consistent with the fact that no parasites have ever been reported in lungs of franciscanas. At the coast of Paraná State (Group 3), other sympatric cetacean species, Sotalia guianensis (Cetacea: Delphinidae), is often found with high pulmonary infections by the nematode Halocercus brasiliensis (Marigo et al., 2000), which could be justified by the close host-specificity of this parasite (Dougherty, 1943).

\section{- Stomachs}

Stomachs from Group 1 are yet to be analyzed. Only two specimens of the acanthocephalan Polymorphus sp. were found in two stomach contents of two individuals from Group 2. Since only one parasite was found in each host, those parasites can be considered rare or even occasional because of their very low prevalence $(2 / 29=6.89 \%)$ and intensity of infection.

Andrade (1996) refers to Anisakis typica, Polymorphus cetaceum and Corynosoma australe in the stomachs of franciscanas from Rio Grande do Sul State. The present results are almost similar to, and may confirm, those results obtained by Santos et al. (1996), where no parasites were found in the stomachs of 42 animals from Rio de Janeiro State. In contrast, the sympatric $S$. guianensis from Rio de Janeiro and Paraná states harbors Anisakis sp. in the stomach (Santos et al., 1996; Marigo et al., 2001).

Overall, the occurrence of a particular parasite in any geographic location depends upon the presence of a suitable host, suitable intermediate host(s), and complex biological factors which impart a strict interdependency on the organisms comprising the host-parasite complex (Dailey and Vogelbein, 1991). In addition, a host's parasite

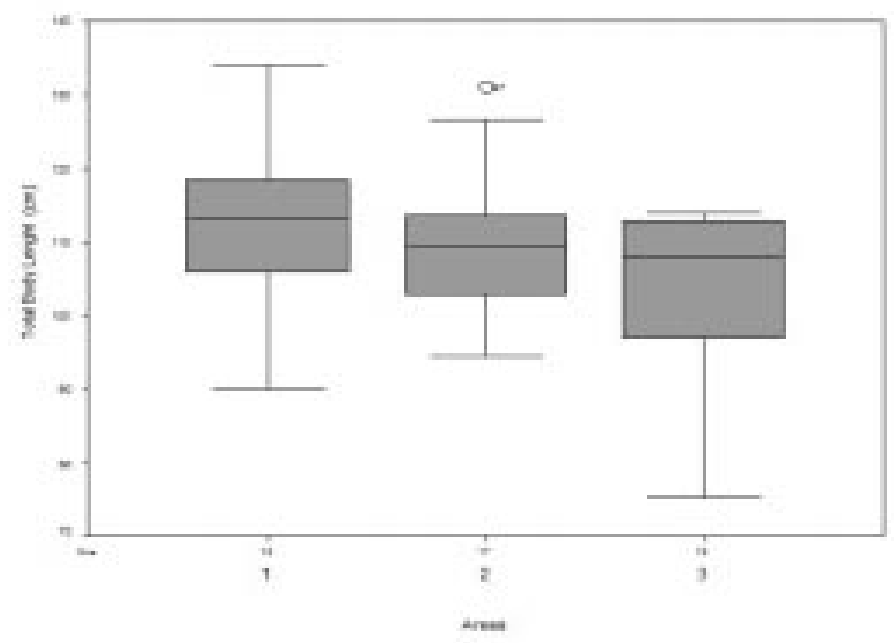

Figure 2. Dispersion of the total body length data (in $\mathrm{cm}$ ) within the various sampling areas. The total number of samples (N) for each area is also shown on the x-axis. (Area 1) Guarujá and Praia Grande, São Paulo State; (Area 2) Cananéia, São Paulo State; (Area 3) Paraná State. 
community can also be viewed as a characteristic of the specific host. Many parasite species are legacies of extinct host ancestors, so similarities between related species of hosts are usually not a result of convergence or recent acquisitions related to host ecology, but probably because they share a recent common ancestor (Poulin, 1996). P. blainvillei and S. guianensis are not phylogenetic closely related, which may explain in part why their parasite community is different, even though they occur in the same habitat. Aznar et al. (1994) mention that Pontoporiidae dolphins have adapted secondarily to freshwater habitats at least three times, and that franciscanas may have had one or several freshwater ancestors, which would involve remarkable habitat shifts for its helminth parasites. Evolutionary restrictions may be responsible for the relatively low richness and diversity of helminths found in the franciscana.

The lack of stomach parasites in specimens from this study, in comparison with specimens from southern Brazil, may be a reflection of differences in the franciscana's food habits and/or the absence of suitable intermediate hosts at lower latitudes.

\section{- Intestines}

In all groups, using a prevalence equal to or greater than $50 \%$ as a criterion to identify the parasite component community, franciscanas also showed a low diversity in the intestinal parasitic fauna, which was represented only by one species, the trematode Hadwenius pontoporiae (Digenea: Campulidae). The prevalence of this parasite was $100 \%$ for Group 1, $82.35 \%$ for Group 2 and $58.33 \%$ for Group 3 (Table 1).

In a previous study, franciscana dolphins from Rio Grande do Sul State (Andrade, 1996) presented a more diverse parasite community, harboring in the intestines three parasite species: H. pontoporiae, Corynosoma australe, and Bolbosoma turbinella. In Uruguay, no parasites have been found in their intestines (e.g. Brownell, 1975; Kagei et al, 1976; Praderi, 1984). Franciscanas from Argentina had H. pontoporiae and Pholeter gastrophilus (Aznar et al., 1994) (Table 2).

Hadwenius pontoporiae does not seem to have a constant distribution in the intestine, occurring only in the initial portion of this organ. This pattern of distribution has been observed in franciscanas from Buenos Aires Province, Argentina (Aznar et al., 1997b), and from Rio Grande do Sul (Andrade, 1996), Paraná and south of São Paulo states (Marigo et al., 1999).

The mean intensity of $H$. pontoporiae for Groups 1, 2 and 3 was 39.5, 25.05 and 13.5 parasites per host, respectively (Table 1). One animal from Group 1 presented a total of 125 H. pontoporiae, and another individual from Group 2 harbored 84 trematodes. The only animal from Ubatuba (a $106 \mathrm{~cm}$ long male), northern coast of São Paulo State,

Table 1. Comparison of identified gastrointestinal helminth species in specimens of Pontoporia blainvillei from São Paulo (Areas 1, 2 - SP), Paraná (Area 3 - PR) and Rio Grande do Sul (RS) states, Brazil, and from Uruguay and Argentina*.

\begin{tabular}{|c|c|c|c|c|c|c|c|c|}
\hline \multirow{2}{*}{ Helminths } & \multirow{2}{*}{ Site } & \multicolumn{4}{|c|}{ Brazil } & \multirow{2}{*}{ Uruguay } & \multirow{2}{*}{ Argentina } & \multirow{2}{*}{ References } \\
\hline & & Area 1 SP & Area $2 \mathrm{SP}$ & Area 3 PR & RS & & & \\
\hline Anisakis typica & $S$ & - & - & - & & & - & $1,2,3$ \\
\hline Anisakis simplex & $S$ & - & - & - & - & - & & 4 \\
\hline Contracaecum sp & S & - & - & - & - & & & $4,5,6$ \\
\hline Procamallanus sp & $S$ & - & - & - & - & & - & 1,3 \\
\hline Hadwenius pontoporiae & S, I & & & & & & & $2,4,7,8$ \\
\hline Polymorphus (P.) cetaceum & $S$ & - & - & - & & & & $1,2,3,4$ \\
\hline Corynosoma australe & $S, I$ & - & - & - & & - & - & 2 \\
\hline Bolbosoma turbinella & $S$ & - & - & - & & - & - & 2 \\
\hline Pholeter gastrophilus & $S$ & - & - & - & - & - & & 4 \\
\hline
\end{tabular}

*Adapted from Andrade, 1996.

( $\square$ ) presence, (-) absence, (S) stomach, (I) intestine

References:

1 - Kagei et al., $1976(\mathrm{n}=1)$

2 - Andrade, $1996(\mathrm{n}=53)$

3 - Praderi, $1984(\mathrm{n}=157)$

4 - Aznar et al., $1994(\mathrm{n}=46)$

5 - Dailey and Brownell, 1972 (n=?)

6 - Brownell, 1975 ( $\mathrm{n}=191)$

7 - Marigo et al., $1999(\mathrm{n}=19)$

8 - Present study $(n=41)$ 
Table 2. Mean intensity (mean number of parasites per specimen) and prevalence (percentage of specimens infected) of the trematode Hadwenius pontoporiae from franciscanas from São Paulo (Areas 1, 2 - SP), Paraná (Area 3 - PR) and Rio Grande do Sul (RS) states, Brazil, and from Argentina.

\begin{tabular}{l|c|c|c|c|c}
\hline \multirow{2}{*}{ Hadwenius pontoporiae } & \multicolumn{4}{|c|}{ BRAZIL } & \multirow{2}{*}{ Argentina } \\
\cline { 2 - 5 } & $\begin{array}{c}\text { Area 1 } \\
\text { SP }\end{array}$ & $\begin{array}{c}\text { Area 2 } \\
\text { SP }\end{array}$ & $\begin{array}{c}\text { Area 3 } \\
\text { PR }\end{array}$ & RS & \\
\hline \hline Mean intensity & 39,5 & 25,05 & 13,5 & 166,3 & 397 \\
\hline Prevalence & $100 \%$ & $82,35 \%$ & $58,33 \%$ & $97,70 \%$ & $100 \%$ \\
\hline References & 1 & 1,2 & 1,2 & 3 & 4 \\
\hline \hline
\end{tabular}

References:

1 - Present study $(\mathrm{n}=41)$

2 - Marigo et al., $1999(\mathrm{n}=19)$

3 - Andrade, $1996(\mathrm{n}=53)$

4 - Aznar et al., $1994(\mathrm{n}=46)$

harbored only 6 H. pontoporiae. The single animal (a $120 \mathrm{~cm}$ long male) from Itanhaém, south of Area 1, harbored 375 parasites, the highest infection level in this study. Sampling wild animals is often opportunistic, so that samples are rarely suitably age-stratified or diverse enough to detect heterogeneity in host-parasite associations (Gulland, 1997).

No significant correlation between total body length and infection levels was observed (Pearson's correlation coefficient $=0.51, p>0.01$ ). Franciscanas from Rio Grande do Sul State showed a negative correlation between mean intensity and total body length and age of the host, suggesting that the immune response increases with age (Andrade, 1996). No significant quantitative differences in parasite infection levels were observed between sexes (males and females from the three areas together, $p=0.239$ and $p=0.721$, respectively). However, recognition of a pattern of sex differences in infections has two potential problems: 1) ensuring a sample large enough to detect a sex difference, if one is present, and 2) distinguishing between differential exposure and differential susceptibility. Sex differences in parasite prevalence or intensity are usually attributed to one of two causes: ecological or physiological, nearly always hormonal in origin (Zuk and McKean, 1996).

Another issue that was not resolved was a possible seasonal variation of infection levels due to the small sample sizes, and also that specimens of franciscana from each group were obtained at different time periods. According to Andrade (1996), seasonal variations, when present, may result not only in changes in the presence of intermediate stages and water temperature, but may also suggest host movements to other areas during a certain period of time.

In this study there was a significant difference between the number of parasites among the three groups (KruskalWallis test, $\mathrm{p}=0.012$ ). Groups 2 and 3 are geographically close, and exhibited non-significant differences in the total number of parasites found (Mann-Whitney test, $\mathrm{p}=0.063$ ). Groups 1 and 3, which are further apart geographically, showed a significant difference in the total number of parasites (Mann-Whitney test, $\mathrm{p}=0.003$ ).
The low infestation levels in specimens from the three groups suggest differences between franciscanas from those groups and franciscanas from Rio de Janeiro State that had no parasites (Santos et al., 1996), as well as from those from Rio Grande do Sul State that harbored H. pontoporiae in all five segments of the small intestine with total mean intensity of 166.3 parasites per host (Andrade, 1996). These differences corroborate with a putative stock subdivision proposed by Secchi et al., (in press b), where franciscanas from Paraná and São Paulo states belong to the same stock whilst franciscanas from Rio Grande do Sul and northern Rio de Janeiro are part of other two stocks. Marigo et al. (1999), in an analysis of 19 animals from Areas 2 and 3, found a significant quantitative difference $\left(\chi^{2}\right.$ test, $\left.\mathrm{p}<0.001\right)$ in the prevalence of $H$. pontoporiae between the intestines of franciscanas from these areas (prevalence $=68.4 \%$ ) and those of franciscanas from Rio Grande do Sul (prevalence $=97.7 \%$; Andrade et al., 1997). This corroborates the hypothesis of different stocks of franciscanas in the two above-mentioned locations, which was already suggested by Pinedo (1991) and Secchi et al. (1998), based on osteological and genetic characteristics, respectively.

A regression analysis of mean intensity as a function of the areas where $H$. pontoporiae was found [Areas 1, 2, 3 (this study), Rio Grande do Sul State, and Argentina] shows a tendency of increase in the response according to the geographic area (Figure 3). And despite the slight decrease in prevalence for Area 3, there is a linear tendency of increase in prevalence with distance as latitudes increase (Figure 4). Those latitudinal trends may reflect differences in the aquatic environment that can affect the parasite cycles, including pollution and water temperature. Aquatic pollution may act on free-living parasite stages, as well on the intermediate or definite host population (Möller, 1987). Some surveys of warm-water fishes show relatively smaller numbers of digenean species than in cold-water fishes, but numbers of fish examined were small or species of only one fish family were examined (Rohde and Heap, 1998). Delyamure (1955) made the first attempt to perform a global zoogeographic analysis on helminths infecting marine 


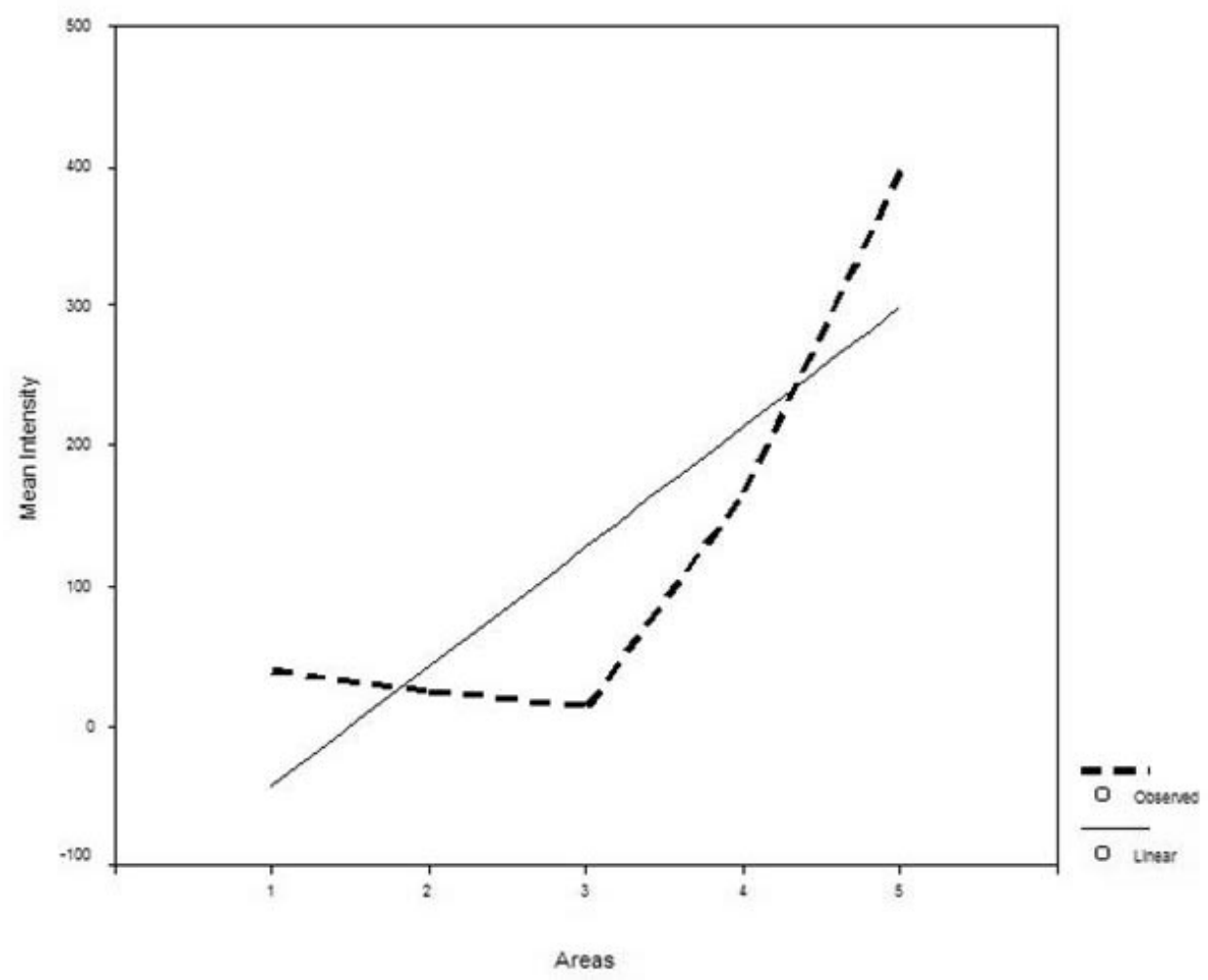

Figure 3. Regression line of mean intensity (mean number of $H$. pontoporiae per host) from the various sampling areas. (Area 1) Guarujá and Praia Grande, São Paulo State; (Area 2) Cananéia, São Paulo State; (Area 3) Paraná State; (Area 4) Rio Grande do Sul State; (Area 5) Argentina.

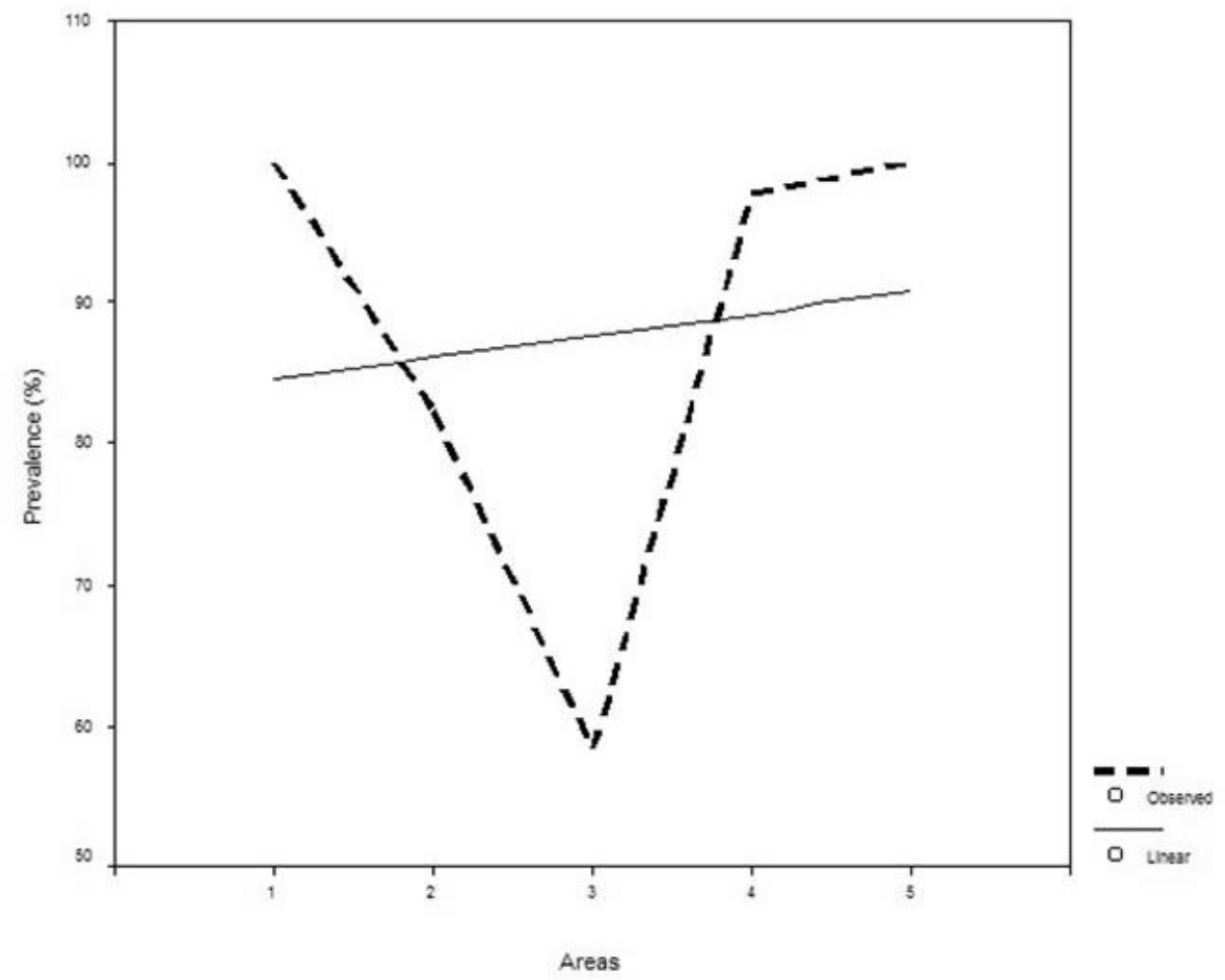

Figure 4. Regression line of the prevalence of $H$. pontoporiae from the various sampling areas. (Area 1) Guarujá and Praia Grande, São Paulo State; (Area 2) Cananéia, São Paulo State; (Area 3) Paraná State; (Area 4) Rio Grande do Sul State; (Area 5) Argentina. 
mammals and found that helminth diversity is high in temperate waters, sharply dropping towards polar areas.

H. pontoporiae may continue to be useful as a biological tag for identifying franciscana's ecological stocks, together with information from genetic, morphometric and other biological studies. However, it is essential that standardized methodology be used in the collection of the parasite data.

\section{Acknowledgements}

We are grateful to all researchers and institutions that provided material and time for this study: Valéria Ruoppolo, Carolina Bertozzi, IPeC (Instituto de Pesquisas de Cananéia, Cananéia, SP), Projeto BioPesca (Praia Grande, SP) and MUZUSP (Museu de Zoologia da Universidade de São Paulo, SP). Fernanda Marques, Toni Raga and Eduardo Secchi provided useful comments on the manuscript. This work is part of the MSc dissertation presented by Juliana Marigo to the Department of Pathology, School of Veterinary Medicine, Universidade de São Paulo, Brazil, and supported by FAPESP grant \# 00/14669-0.

\section{References}

Andrade, A.L.V. (1996) Comunidade componente de helmintos gastrointestinais da Franciscana, Pontoporia blainvillei (Cetacea, Pontoporiidae) no Rio Grande do Sul, Brasil, e sua utilização como marcador biológico na identificação de estoques. MSc Thesis. Universidade do Rio Grande, Rio Grande. 98pp.

Andrade, A., Pinedo, M.C. and Pereira Jr., J. (1997) The gastrointestinal helminths of Franciscana, Pontoporia blainvillei, in southern Brazil. Report of the International Whaling Commission 47: 669-73

Aznar, F.J., Balbuena, J.A. and Raga, J.A. (1994) Helminths communities of Pontoporia blainvillei (Cetacea: Pontoporiidae) in Argentinian waters. Canadian Journal of Zoology 72: 1-5.

Aznar, F.J., Raga, J.A., Corcuera, J. and Monzón, F. (1995) Helminths as biological tags for franciscana (Pontoporia blainvillei) (Cetacea: Pontoporiidae) in Argentinian and Uruguayan waters. Mammalia 59(3): 427-435.

Aznar, F.J., Raga, J.A., Corcuera, J. and Monzón, F. (1997a) Los parásitos, un posible método para diferenciar stocks y detectar migraciones en las franciscanas. Pages 13-22 in Pinedo, M.C. and Barreto, A.S. (Eds) Anais do $2^{\circ}$ Encontro sobre Coordenação de Pesquisa e Manejo da Franciscana. Ed. FURG, Rio Grande.

Aznar, F.J., Balbuena, J.A., Bush, A.O. and Raga, J.A. (1997b) Ontogenetic habitat selection by Hadwenius pontoporiae (Digenea: Campulidae) in the Intestine of franciscanas (Cetacea). Journal of Parasitology 83(1): 13-18.

Balbuena, J.A., Aznar, F.J., Fernández, M. and Raga, J.A. (1995) Parasites as indicators of social structure and stock identity of marine mammals. Pages 133-139 in Blix, A.S., Walloe, L. and Ultang, O. (Eds) Whales, seals, fish and man: Developments in Marine Biology. Proceedings of the International Symposium on the Biology of Marine Mammals in the north east Atlantic. 29 nov -1 dec. 1994. Elsevier Science Publishers Ltd., London. xiii+720pp.

Bertozzi, C.P. and Zerbini, A.N. (2002) Incidental mortality of franciscana, Pontoporia blainvillei, in the artisanal fishery of Praia Grande, São Paulo State, Brazil. Latin American Journal of Aquatic Mammals (special issue) 1: 153-160.

Brownell Jr., R.L. (1975) Progress report on the biology of the franciscana dolphin Pontoporia blainvillei, in Uruguayan waters. Journal of the Fisheries Research Board of Canada 32(7): 1073-1078.
Dailey, M.D. and Brownell Jr., R.I. (1972) A checklist of marine mammals parasites. Pages 528-589 in Rigdway, S.R. (Ed.) Mammals of the Sea, Biology and Medicine. Charles C. Thomas, Springfield, Illinois.

Dailey, M.D. (1978) Preparation of parasites for identification and cataloging. Journal of Zoo Animal Medicine 9(1): 13-15.

Dailey, M.D. and Vogelbein, W.K. (1991) Parasite fauna of three species of Antarctic whales with reference to their use as potential stock indicators. Fishery Bulletin 89(3): 355-365.

Delyamure, S.F. (1955) Helminthofauna of marine mammals. Academy of Science of the U.S.S.R., Moscow.(Translated by M. Raveh, Israel Scientific Translations, Jerusalem, Israel, 1968). 522pp.

Dougherty, E.C. (1943) Notes on the lungworms of porpoises and their occurrence on the California coast. Proceeding of the Helmintological Society of Washington 10(1): 16-22.

Fernández, M., Balbuena, J.A., Pertusa, J.F. and Raga, J.A. (1995) Biometric variability of Hadwenius tursionis (Marchi, 1873) (Digenea, Campulidae) from the intestine of the bottlenose dolphin Tursiops truncatus (Montagu, 1821). Systematic Parasitology 30: 67-76.

Gardiner, C. (2000) Personal communication.

Gulland, F.M.D. (1997) The impact of parasites on wild animal populations. Parasitologia 39: 287-291.

IBAMA (1997) Mamíferos aquáticos do Brasil: Plano de Ação. Instituto Brasileiro do Meio Ambiente e dos Recursos Naturais Renováveis, Brasília. 80pp.

Kagei, N., Tobayama, T. and Nagasaki, Y. (1976) On the helminthum of franciscana Pontoporia blainvillei. Scientific Report of the Whales Research Institute 28: 161-166.

Mackenzie, K. (1987) Parasites as indicators of host populations. International Journal of Parasitology 17: 345-352.

Marigo, J., Rosas, F.C.W. and Andrade, A.L.V. (1999) Intestinal parasites of Sotalia fluviatilis guianensis and Pontoporia blainvillei from the States of Paraná and São Paulo, Brazil. Page 114 in Abstracts, XIII Biennial Conference on the Biology of Marine Mammals. 28 November - 03 December 1999, Maui, Hawaii.

Marigo, J.; Andrade, A.L.V. and Rosas, F.C.W. (2000) Parasitos pulmonares de cetáceos do litoral do Estado do Paraná, Brasil. Page 82 in Abstracts, 9a Reunião de Trabalho de Especialistas em Mamíferos Aquáticos da América do Sul, 30 October - 3 November 2000, Buenos Aires, Argentina.

Marigo, J., Andrade, A.L.V., Oliveira, M.R. and Rosas, F.C.W. (2001) Parasitos estomacais de Sotalia fluviatilis guianensis (Cetacea: Delphinidae) do litoral do Paraná, Brasil. Page 14 in Abstracts, X Encontro Nacional de Patologia Veterinária, 21-25 July, 2001, Campus Administrativo de Pirassununga, USP, São Paulo.

Möller, H. (1987) Pollution and parasitism in the aquatic environment. International Journal of Parasitology 17: 345-352.

Moser, M. (1991) Parasites as biological tags. Parasitology Today 7(7): 182-185.

Pinedo, M.C. (1991) Development and variation of the franciscana, Pontoporia blainvillei. PhD Thesis. University of California, Santa Cruz. 406pp.

Praderi, R. (1984) Mortalidad de Franciscana, Pontoporia blainvillei, en pesquerias artesanales de tiburón de la costa Atlântica Uruguaya. Pages 259-272 in Actas, III Reunión Iberoamericana de Conservacion y Zoologia de Vertebrados, 15-19 November 1992, Buenos Aires

Price, E. (1932) The trematode parasite of marine mammals. Proceedings of the United States National Museum 81(13): 1-68.

Poulin, R. (1996) Patterns in the evenness of gastrointestinal helminths communities. International Journal of Parasitology 26(2): 181-186.

Raga, J.A., Aznar, F.J., Balbuena, J.A. and Dailey, M.D. (1994) Hadwenius pontoporiae sp. n. (Digenea: Campulidae) from the intestine of Franciscana (Cetacea: Pontoporiidae) in Argentinian waters. Journal of the Helminthological Society of Washington 61(1): 45-49. 
Reeves, R.R. and Leatherwood, S. (1994) Dolphins, porpoises, and whales: 1994-1998 Action Plan for the Conservation of Cetaceans. IUCN, Gland.

Rohde, K. and Heap, M. (1998) Latitudinal differences in species and community richness and in community structure of metazoan endo- and ectoparasites of marine teleost fish. International Journal of Parasitology 28: 461-474.

Rosas, F.C.W. (2000) Interações com a pesca, mortalidade, idade, reprodução e crescimento de Sotalia guianensis and Pontoporia blainvillei (Cetacea: Delphinidae e Pontoporiidae) no litoral sul do Estado de São Paulo e litoral do Estado do Paraná, Brasil. PhD Thesis. Universidade Federal do Paraná, Curitiba. 145pp.

Santos, C.P., Rohde, K., Ramos, R. and Di Beneditto, A.P. (1996) Helminths of cetaceans on the southeastern coast of Brazil. Journal of the Helminthological Society of Washington 63(1): 149-152.

Santos, M.C.O., Vicente, A.F.C., Zampirolli, E., Alvarenga, F. and Souza, S.P. (2002) Records of Franciscana (Pontoporia blainvillei) from the coastal waters of São Paulo State, Southeastern Brazil. Latin American Journal of Aquatic Mammals (special issue) 1: 169-174.

Secchi, E.R., Wang, J.Y., Murray, B.W., Rocha-Campos, C.C. and White, B. (1998) Population differentiation in the franciscana (Pontoporia blainvillei) from two geographic locations in Brazil as determined from mitochondrial DNA control region sequences. Canadian Journal of Zoology 76: 1622-1627.

Secchi, E.R., Ott, P.H., Crespo, E.A., Kinas, P.G., Pedraza, S.N. and Bordino, P. (2001) A first estimate of franciscana (Pontoporia blainvillei) abundance off southern Brazil. Journal of Cetacean Research and Management 3: 95-100.

Secchi, E.R., Ott, P.H. and Danilewicz, D.S. (in press a) Effects of fishing by-catch and conservation status of the franciscana dolphin, Pontoporia blainvillei in Gales, N., Hindell, M. and Kirkwood, R. (Eds) Marine mammals and humans: towards a sustainable balance. Melbourne University Press, Melbourne.

Secchi, E.R., Danilewicz, D. and Ott, P.H. (in press b) Applying the phylogeographic concept to identify franciscana dolphin stocks: implications to meet management objectives. Journal of Cetacean Research and Management.

Szidat, L. (1964) La Parasitologia como ciencia auxiliar para la biogeografia de organismos marinos. Boletin del Instituto de Biología Marina, Mar del Plata - Arg, nº 7, October 1964.

Walker, W.A. (2001) Geographical variation of the parasite, Phyllobothrium delphini (Cestoda), in Pacific Dall's porpoises, Phocoenoides dalli, in the northern North Pacific, Bering Sea, and Sea of Okhostok. Marine Mammal Science 17(2): 264-275.

Zuk, M. and McKean, K. (1996) Sex differences in parasite infections: patterns and processes. International Journal of Parasitology 26(10): 1009-1024.

Yamaguti, S. (1963) Acanthocephala in Systema Helminthum, vol. 5. Wiley Interscience Publ.Co., New York. 423pp.

Yamasaki, F., Takahashi, K. and Kamiya, T. (1975) Digestive tract of la Plata dolphin, Pontoporia blainvillei. II. Small and Large Intestines. Okajimas Folia Anatomica Japonica 52: 1-26. 